\title{
Erratum to: Human-Grey parrot (Psittacus erithacus) reciprocity: a follow-up study
}

\author{
Franck Péron • Luke Thornburg • Brya Gross • \\ Suzanne Gray · Irene M. Pepperberg
}

Published online: 25 February 2014

(c) Springer-Verlag Berlin Heidelberg 2014

\section{Erratum to: Anim Cogn}

\section{DOI 10.1007/s10071-014-0726-3}

Unfortunately, one of the co-authors' names was incorrectly published in the original publication. The name of the author should read as Luke Thornburg instead of Luke Thornberg.

The online version of the original article can be found under doi:10.1007/s10071-014-0726-3.

F. Péron

School of Life Sciences, Faculty of Science, University of

Lincoln, Riseholme Park, Lincoln, Lincolnshire LN2 2LG, UK

L. Thornburg · S. Gray · I. M. Pepperberg ( $\square)$

Department of Psychology, Harvard University,

Cambridge, MA 02138, USA

e-mail: impepper@media.mit.edu

B. Gross · S. Gray · I. M. Pepperberg

Department of Psychology, Brandeis University,

Waltham, MA 02454, USA 